\title{
From Academia to Start-up: A Case Study with Implications for Engineering Education
}

\author{
http://dx.doi.org/10.3991/ijep.v4i1.3236 \\ Bill Williams ${ }^{1,2}$ and José Figueiredo ${ }^{2}$ \\ ${ }^{1}$ Instituto Politécnico de Setúbal, Setúbal, Portugal \\ ${ }^{2}$ Universidade de Lisboa, Lisboa, Portugal
}

\begin{abstract}
This study uses the characterization of contrasting modes of knowledge production to follow the activity of a group of engineers who migrated from an academic environment to a successful start-up firm. Qualitative data from interviews of two key members of the team were used to characterize their activities in the two settings. The authors relate the engineering practice described in the interviews to the Gibbons Mode 1 and Mode 2 knowledge production phases and note the importance of a phase change in the transition between the two modes. The resultant casestudy contributes material for use in role-play activity with engineering students to help develop interdisciplinary skills. The study also presents a critical analysis to evaluate the merits of the Mode 1 and Mode 2 framework for analysis of engineering practice at the level of the firm.
\end{abstract}

Index Terms-Case-study, engineering practice, knowledge production, role-play.

\section{INTRODUCTION}

Many students graduating from engineering schools soon encounter a very different world when they start working in a professional engineering environment and recent studies have clarified some of the differences [e.g. $1,2,3,4,5,6,7$ and 8]. One difference lies in how knowledge is produced [9]. The publication of The New Production of Knowledge [10] led to considerable attention being focussed on two distinct models of research, identified by the authors as Mode 1 (associated with a traditional academic discipline-based approach) and the more recently emerged Mode 2 (a context-driven and problem-focused process more common in the entrepreneurial domain). We have interpreted in Table 1 the differences between these two approaches as characterized by Figueiredo and Cunha [9].

Although the practice of engineering design in academia and industry have tended to converge towards a Mode 2 approach, as yet there is sparse evidence that this has been accompanied by corresponding developments in the engineering education. Jorgensen [11] argues that educational reforms have tended to focus on the development of Mode 1 model leading to a "crisis in engineering design". He suggests there is a need for a re-thinking of the "missing elements in engineering teaching" so as to prepare future professionals to face the challenges arising from contemporary technological innovation.

To help address the issue of Jorgensen's "missing elements" this paper has the following structure: after introducing the background to the case-study and respective methodology, data from interviews is presented followed
TABLE I.

PARAMETERS ASSOCIATED WITH GIBBONS' MODES 1 AND 2 OF KNOWLEDGE PRODUCTION

\begin{tabular}{|c|c|c|}
\hline & Mode 1 & Mode 2 \\
\hline Context & academic, scientific & $\begin{array}{l}\text { economic and social applica- } \\
\text { tions }\end{array}$ \\
\hline Innovation & linear & $\begin{array}{l}\text { problems are set and solved in } \\
\text { the context of application }\end{array}$ \\
\hline Community & $\begin{array}{l}\text { disciplinary, homo- } \\
\text { geneous teams, } \\
\text { university based }\end{array}$ & $\begin{array}{l}\text { transdisciplinary; networked; } \\
\text { heterogeneous actors }\end{array}$ \\
\hline Orientation & $\begin{array}{l}\text { explanation, incre- } \\
\text { mental }\end{array}$ & solution focused \\
\hline Method & $\begin{array}{l}\text { replicability is } \\
\text { important }\end{array}$ & $\begin{array}{l}\text { replicability not vital ( there } \\
\text { may be secrecy/copyright } \\
\text { issues) }\end{array}$ \\
\hline Quality assurance & $\begin{array}{l}\text { peer-review is cen- } \\
\text { tral }\end{array}$ & $\begin{array}{l}\text { context dependent: may } \\
\text { involve peer-review; custom- } \\
\text { er satisfaction }\end{array}$ \\
\hline $\begin{array}{l}\text { Definition of } \\
\text { success }\end{array}$ & scientific excellence & $\begin{array}{l}\text { efficiency; satisfy multiple } \\
\text { stakeholders: commercial } \\
\text { success }\end{array}$ \\
\hline
\end{tabular}

by an analysis of the findings from the perspectives of engineering pedagogy and of engineering practice research.

\section{BACKGROUND}

This study is relevant to two areas of study: case-study based role-play as a pedagogical tool in engineering education and engineering practice studies. In the next two sections we will outline pertinent prior literature in these two areas.

\section{A. Case-study based role-play as a pedagogical tool in engineering education}

A recent paper by James Trevelyan, whose team at the University of Western Australia has amassed considerable empirical data about engineering practice, argues for "relocating engineering studies from the curricular margins to the core of engineering education and research"[6]. This perspective is reinforced by studies of new-engineer adjustment in companies that suggest that few novice engineers have the experience or knowledge to locate their technical competence and professional ideology within the organizational context [12] and others which show that in companies which systematically employ organizational socialization tactics that these strongly influence newcomer integration and task mastery which in turn lead to increased satisfaction and organizational commitment [13]. 
This perspective would seem to make a strong case for including a greater emphasis on socio-technical professional skills as part of undergraduate training. Various institutions have attempted to design or redesign engineering and technology courses to address such issues by adopting pedagogical approaches such as service learning [14] problem-based learning [15], case-studies [16], decision-making games and role-play [17], or virtual simulations [18] to help students develop attributes and thinking styles more appropriate for industrial practice [19]. As yet, however, no widely-used methodology has emerged to assess the effectiveness of such initiatives, an aspect to which we shall return in section VIII $B$.

With the increased inclusion of Entrepreneurship in engineering and engineering management courses, casestudies have come to be seen as a useful pedagogical approach and journal articles focusing on real-life casestudies have become more common (see for example the International Journal of Entrepreneurship and Innovation and the International Journal of Entrepreneurship and Innovation Management).

\section{B. Engineering practice studies}

At a symposium entitled Engineering as a Social Enterprise organized by the US National Academy of Engineering in 1990, Walter Vincenti pointed out that "engineering functions inseparably from the society of which it is part" and he went on to suggest that "to perform engineering's task as a social enterprise" engineering practice needed to be better understood [20]. In the intervening years there has been a growing body of empirical data about this topic but due to the research being dispersed in a variety of fields [21, 22, 323, 24, 25 and 26] it has been difficult, as yet, to examine this data in such a way as to permit a global portrait of what engineers do. The authors have proposed that engineering practice should be viewed as an autonomous field of research and argued that it has an important role to play in preparing engineers for the future challenges of the profession [27]

Two conceptual models which have been proposed by policy makers to help understand the interplay of research, technology and business are the Triple Helix [28] and the New Production of Knowledge [29]. The former uses a coevolution model to characterize the relationship between university, industry and government in an increasingly knowledge-based social order. The New Production of Knowledge perspective, on the other hand, argues that the way in which scientific knowledge, technical practices, industry, education and society at large are organized are changing and they identify two distinct modes of knowledge production. Mode 1 is characterized by activity in the autonomous university with few direct links to industry. By contrast, Mode 2 knowledge production takes place in the domain of business and entrepreneurship and its parameters are different to those of Mode 1 research and knowledge production in a number of important ways as we have summarised earlier in Table 1.

Although both of these perspectives have been widely explored [30] there has also been attention drawn to potential weaknesses in their application to empirical data. Shinn comments that the Gibbons framework was proposed "with almost no concrete evidence is given for the assertions advanced; and no provision is made for future empirical (...) work." [30] By contrast, he notes that although The Triple Helix was founded on a central core of empirical data, these are meta-level data presented in macroscopic terms and this constitutes a problem in that "the search for appropriate units of analysis takes place at a high level of aggregation, generalization and abstraction".

\section{RESEARCH QUESTIONS AND METHODOLOGY}

Considering the above two fields of study, the following two research questions emerged:

What useful data can be obtained on the history of decision making in an innovative engineering company using the Mode 1 and 2 model as a framing construct?

What implications for engineering education are suggested?

As this was a preliminary study, an exploratory casestudy methodology [35] with a narrative approach was adopted.

At the time when the work began in 2009 , there had been relatively few studies published with empirical data about engineering practice [27] and the authors found no published framework or model to represent what engineers do. In her paper Building Theories from Case Study Research, Kathleen Eisenhardt [31] suggests that smallscale case studies can be particularly valuable for theory building in the early stages of research on a topic or when the research is in an area where existing theory seems inadequate. Accordingly it was decided to choose a firm that was a recognised innovation leader and use a narrative approach based around an appropriate framing construct.

The narrative approach has been gaining recognition among scholars as a research method and process [32, 33] and Steve Denning's recent work also champions narrative as a tool for organizational change [34]. It was adopted with the intention of building on the initial qualitative data to design a larger scale quantitative study to test or generalize the insights from the case study [35]. This aspect will be returned to in the Conclusions section.

\section{1) The company selected for the case study}

When management guru Gary Hamel's consultancy firm Strategos polled 186 CEOs and senior figures in leading Portuguese companies to gather data on which international and national firms they considered to be the most innovative [1] the Portuguese company with the highest vote was YDreams, a start-up created in 2000 when a group of engineers from a successful university research department at a Lisbon university (Universidade Nova de Lisboa) felt the need to move from a university to an entrepreneurial context. The group was part of a successful university research department at the New University of Lisbon throughout the 90's in the field of environmental engineering and IT. Their Environmental Systems Analysis Group (GASA) was known for its pioneering work in a field that has since become dominated by Google Maps. In 2000, frustrated by the limitations encountered within the academic system, they effectively set aside the projects they had been working on and dedicated themselves to an entrepreneurial start-up.

Their YDreams Company has since come to enjoy considerable international success in the interactive space and augmented reality sectors. With an initial investment of 50 thousand euros in 2000 , by 2010 the firm reportedly 
had an annual turnover of over 9 million euros and its clients have included Vodafone, NOKIA, JC Decaux Airport, Siemens, Alcatel, Endemol and the BBC. CEO Antonio Câmara won the prestigious Pessoa Prize in 2006 [53] for his entrepreneurial achievements and the company has won a number of international awards including the Industrial Design Society of America Gold Award for Interactive Environments in 2004, and an Auggie (Augmented Reality Award) in 2010.

\section{2) Construct chosen to frame the data}

Of the two constructs described in section II $A$ given that the Triple Helix is more appropriate to macro-level analysis and that the Gibbons Mode 1 and 2 approach can address both academic and entrepreneurial contexts at meso and micro level, the latter was adopted. Therefore the study considers the work of the group of Portuguese engineers who founded YDreams over a period of approximately 15 years using the Mode 1 and Mode 2 characterizations and looks for appropriate lessons which can be applied to engineering education to better prepare future engineers.

\section{PROCEDURE}

Separate interviews were carried out with two senior members of the group involved in both phases: António Câmara, CEO of YDreams and former head of the GASA group and Edmundo Nobre, YDreams administrator (CFO) and co-founder. The interviewees were previously sent a brief summary of the intended case-study, which included Table 1, and during the individual interviews were invited to freely relate their experiences rather than respond to a fixed set of questions although occasional follow-on questions were posed by the interviewer where it was felt clarification was needed.

The interview transcripts were subsequently analysed for sections relevant to the 7 parameters listed in Table 1 relating to either Mode 1 or 2 of the Gibbons model. The analysis was returned to the interviewees to allow them to confirm the quotations.

In the following sections we selected what we consider relevant portions of the interviews and present first those relating to the pre-2000 research group GASA. In the description of the research group phase we show the Mode 1 characterisation for each parameter as set out in Table 1 and also include the corresponding Mode 2 characterization in italic typeface. In the entrepreneurial phase we use the opposite convention so that in this case the Mode 1 characterization is in italic.

\section{INTERVIEW DATA}

\section{A. Research group Phase: GASA}

\section{1) Context}

\begin{tabular}{l|l}
\hline academic, scientific & economic and social applications
\end{tabular}

António Câmara (CEO): Well, we were engineers but we were doing work that was engineering/science where we were essentially emulating the approach of the physical sciences, and not really engineering as such.

Edmundo Nobre (CFO): Environmental engineers have always had a wide-ranging approach by the nature of their very general training.

CEO: University groups tend to follow the logic of academia and academic publication and we had a lot of peo- ple working on theories of interaction in a way largely oriented to emulating the sciences rather than developing products. We were creating new worlds but following an existing academic model.

\section{2) Innovation}

\begin{tabular}{|c|l|}
\hline linear & $\begin{array}{l}\text { problems are set and solved in the context } \\
\text { of application }\end{array}$ \\
\hline
\end{tabular}

CEO: For example, Conservation International, which has Harrison Ford as its vice-chair, was looking for a visualization system to represent the impact of forest fires on Amazonia and resulting climate change. We submitted a proposal based on our visualization models whereas MIT Media Lab presented a demonstration created by the people who had done the special effects for the film Titanic. The difference being that they already had an operational prototype, a finished product, while we had only a complex model. So, obviously, Conservation International chose them and this episode really got us thinking, made me alter my own perspective quite radically and made me realize that however good our work was technically, we were never going to get very far in today's world using an academic approach.

So while our thinking was "ride the wave", Media Lab was aiming to "put man on the moon" and in the university context it was extremely difficult to create any kind of multidisciplinary laboratory like they had, almost impossible in fact, because there were all kinds of barriers stemming from the fact that we worked within academic disciplines. So, when we worked in the Environment Department we were expected to be dedicating ourselves to working on the environment, even if we were able to come up with something useful for automobiles ...

\section{3) Community}

\begin{tabular}{|l|l|}
\hline $\begin{array}{l}\text { disciplinary, homogeneous } \\
\text { teams }\end{array}$ & $\begin{array}{l}\text { transdisciplinary; networked; heteroge- } \\
\text { neous actors }\end{array}$ \\
\hline
\end{tabular}

CEO: It was basically research work and recognition came from other researchers. In other words, our community was that of investigators the world over within our area.

CFO: We were always in contact with the best work going on internationally and made a point of encouraging our graduates to go to work at the top research centers. They in turn often stayed on and tended to cite our work which gave us more visibility.

CEO: Then at a certain stage we came up against other communities, ones like MIT, not the traditional scientific community, who were leaders in the field and this was something of a shock for us.

\section{4) Orientation}

\begin{tabular}{|l|l}
\hline explanation, incremental & solution focussed \\
\hline
\end{tabular}

CEO: At GASA it was basically the kind of scholarly approach to which the majority of university courses here aspire; which means that they were very much built around knowledge, scientific knowledge, stabilized knowledge.

CFO: We had the first virtual reality lab in Portugal, created for Expo 98 in Lisbon, complete with a set of instruments that were groundbreaking in world terms at that time in the area of over land navigation. We were the first country to have this infrastructure set up but it dwindled out, because policy-wise its value wasn't recognized. It was an over-ambitious project, probably ahead of its 
time, and like so many other breakthroughs within universities because there isn't an entrepreneurial or commercial perspective then things get bogged down and bit by bit come to a halt.

\section{5) Method}

\begin{tabular}{|l|l}
\hline replicability is important & replicability not vital
\end{tabular}

CFO: Our objective at that time was to produce papers whereas we came to see that at other centres like MIT the object was more to produce enterprises and so they had an applied research approach and received a lot of financial support from industry.

Now MIT had funding to buy super-computers whereas we here could only invest in people, people who were capable of developing powerful algorithms which allowed us to overcome our less advanced hardware and what we achieved was certainly on a par with the best we saw at international level.

\section{6) Quality assurance}

\begin{tabular}{|l|l|}
\hline peer-review is central & $\begin{array}{l}\text { context dependent: may involve } \\
\text { peer-review; customer satisfaction }\end{array}$ \\
\hline
\end{tabular}

CEO: We were, of course, very aware of ISI indexing (...) and getting our work accepted for major conferences which are extremely competitive, with an acceptance rate of around $3 \%$.

\section{7) Definition of success}

\begin{tabular}{|l|l|}
\hline scientific excellence & $\begin{array}{l}\text { efficiency; satisfy multiple stake- } \\
\text { holder; commercial success }\end{array}$ \\
\hline
\end{tabular}

CEO: What we basically wanted was to achieve worldwide recognition within the academic milieu through papers, articles and later books.

\section{B. Start-up Phase - YDreams}

\section{1) Context

\begin{tabular}{|l|l|}
\hline academic, scientific & economic and social applications \\
\hline
\end{tabular}

CEO: I realized that to be competitive with the top laboratories in our field we would need to have professional level management, accounts, public relations ... in short to have an enterprise-like structure.

CFO: We had come to the conclusion that if we couldn't do what we aimed to do within the academic system then we would have to do it on the outside; so basically we went ahead and set up the company.

CFO: When we first set up YDreams, the wide-ranging background of our team stood us in good stead. Now this transdisciplinary approach has paid off and in fact we have people who originally trained as environmental engineers holding down key positions in accounts, programming and project management.

Whereas in our GASA days we used to play around with ideas and ask "OK, how could we get this on the market?" now it was more in a case of "OK, how can what we do that will be important for the market?"

\section{2) Innovation}

\begin{tabular}{|l|l|}
\hline linear & $\begin{array}{l}\text { problems are set and solved in the context of applica- } \\
\text { tion }\end{array}$
\end{tabular}

CFO: We have our R\&D section, YLabs, which has a variety of functions and these include:

- assisting in developing the technological infrastructure for the company itself
- short-term research focused mainly on product development for our clients

- long-term research which is looking to identify future paradigm shifts so that we can be right there when things are happening. In this respect, I would give the example of our work on interactive spaces which up to now has been entirely in the digital domain but as this sector has become successively more the province of large international competitors, we have to be agile and so we have been working on the application of recent innovations in materials sciences and bubble-jet technology to apply our know-how to the development of novel interactive spaces in the physical domain.

\section{3) Community}

\begin{tabular}{|l|l|}
\hline $\begin{array}{l}\text { disciplinary, homogeneous } \\
\text { teams }\end{array}$ & $\begin{array}{l}\text { transdisciplinary; networked; } \\
\text { heterogeneous actors }\end{array}$ \\
\hline
\end{tabular}

CEO: Now I would say that our community is completely different: we do what we do so as to satisfy two groups of people: our clients and our investors.

\section{4) Orientation}

\begin{tabular}{l|l} 
explanation, incremental & solution focussed
\end{tabular}

CFO: We set out to adapt our practice from the GASA days to create a structure which was much more dedicated to industry, with a strong focus on applied research, one which would in turn be supported by industry. Our focus was to be on the real world products rather than on publications. We aim to be a cutting edge company.

\section{Method}

\begin{tabular}{|l|l|}
\hline replicability is important & replicability not vital \\
\hline
\end{tabular}

CEO: Now it really feels like we are doing engineering design and that we have left the world of classic research. One consequence of this is that now when we produce something new our first priority is to take out a patent and if we have time afterwards we may write it up in a paper. So this changes the dissemination process quite radically.

In the company we have continued to carry out research, the difference being that now we are very much more in the Man on the Moon mould. Now we really want to create products and the objective of all our research, pure or applied, is precisely product-focused. We are not at all interested in replicability- we want to be unique, that's what it's all about!

\section{5) Quality assurance}

\begin{tabular}{|l|l|}
\hline peer-review is central & $\begin{array}{l}\text { context dependent: may involve } \\
\text { peer-review; customer satisfaction }\end{array}$ \\
\hline
\end{tabular}

CEO: So we are creating intellectual property, very important to appeal to clients and this has been fundamental in attracting investors in the various phases the company has gone through. To be competitive we have to bring value to the market.

\section{6) Definition of success}

\begin{tabular}{|l|l|}
\hline scientific excellence & $\begin{array}{l}\text { efficiency; satisfy multiple stake- } \\
\text { holders; commercial success }\end{array}$ \\
\hline
\end{tabular}

CFO: We originally wanted to leave academia and conquer the world! Success for us has two dimensions: obviously we want to become millionaires (laughs) but on the other hand we would like to be a company which helps give Portugal a strong international technological presence on a par with, say, what Nokia has in Finland. That is a 
PAPER

FROM ACADEMIA TO START-UP: A CASE STUDY WITH IMPLICATIONS FOR ENGINEERING EDUCATION

company which altered their national panorama and we would like to think we could one day make a similar claim, that is to really make the difference between what Portugal is today and what it could achieve tomorrow help to create a technology driven nation.

\section{DISCUSSION}

The data presented suggest that although there was a predominance of Mode 1 characteristics in the GASA phase, there were already some signs of a Mode 2 in that there was a degree of transdisciplinarity in the research team and a concern with providing solutions to clients (creating virtual instruments for Expo 98, competing with MIT for projects). Equally, in the current entrepreneurial context, although the interviews would indicate a strongly Mode 2 perspective overall, it is worth mentioning that the YDreams headquarters adjoins the university campus where GASA used to operate, the CEO continues to lecture there and there appears to be a certain degree of synergy between the two so it is probably true to say there hasn't been a complete abandonment of the Mode 1 ethos. So although the Mode 1 and 2 characterizations are seen to be useful here as a way of characterizing in a broad sense the knowledge production activity of the group of engineers in question and they help us accompany what seems to have been a significant phase change in the work of the group, it should not be seen as an either/or way of describing the real-world activity involved.

The interviews show a growing awareness of the constraints of the Mode 1 context the group operated in during the 90's ("things got bogged down"; frustration with "ride the wave" thinking) which reached a critical point in the year 2000 when they decided to set up YDreams. This point can be considered a phase change in the sense that the term is employed in systems and complexity theory to refer to a system in a given state which undergoes progressive disruption and achieves equilibrium by transition to a new state [36].

\section{A. The use of Gibbons' Mode 1 and 2 Model in the case study}

Although this exploratory analysis was intended to serve to lead to a subsequent quantitative analysis, the application of the Gibbons framework did not provide an obvious indication as to where subsequent research might move forward. This gives some confirmation to criticisms of the concept as lacking in programmatic and methodological components which could provide a systematic framework for scholarly inquiry [30].

On the other hand, once the interview transcript had been analyzed as described earlier, the authors then applied a phenomenological bracketing procedure [54] to the data included in the Gibbons framework analysis and reexamined the remaining interview data. This provided two relevant aspects arising from the quotations below from the CFO and CEO.

CFO: Right now, I recall off the top of my head that our head of Quality, head of Research, head of Software, our top programmer and the account managers of our best accounts all come from an environmental engineering background and this pluri-disciplinarity, the capacity to handle a broad sweep of areas, is very valuable in a company like ours. These roles involve heading up teams where skills of dealing with both a range of multidisciplinary projects and with their commercial aspects are vital. Obviously when we get to the execution, programming, design and so on then we will call upon our specialized people for these very specific functions.

CEO: What worries me is that engineering courses in our national universities don't have a tacit curriculum like you can find at top international institutions: our graduates have the technical skill; they can solve problems but are not good at explaining them. One feels they were well trained in problem-solving but at the expense of important skills like analyzing, communicating and debating which contribute to the kind of structured thinking we need.

Noting that a significant number of engineers in the company were in posts of responsibility outside conventional engineering domains and that the CEO identifies communication skills as a priority for success, has lead us to see limitations in our original model of engineering practice which was based around engineering design and knowledge production and encouraged us to look for alternatives, particularly for models based on an empirical approach. Accordingly the next step of our research involved gathering empirical data on the activities of engineers in companies and the time they devoted to these activities. This was achieved by collecting quantitative information via an online survey of 247 engineers and qualitative information through semi-structured interviews with 23 practicing engineers in a range of contexts ranging from SMEs to large national and international marketleaders. This in turn allowed us to propose a visual representation of the engineer in the workplace using an actornetwork approach which we published in a recent book [8]

\section{LIMITATIONS OF THE STUDY}

The fact that only one company was studied and only two senior staff members contributed does limit the degree of generalizability. In exploring a single case the authors align with a growing trend in academy that recognizes that the single case may promote reflection and generate useful theory $[37,38]$. It was mentioned in section III that Kathleen Eisenhardt [39] suggests that smallscale case studies can be particularly valuable for theory building in the early stages of research on a topic. She also claims out that testing existing theory on case studies may provide serendipitous findings which can lead to new insights. As was explained in the previous section, this particular case study did lead to valuable insights which enabled the authors to identify fruitful lines of inquiry for a successful large-scale study.

Moreover, the case described reinforces our idea that our approach is academically appropriate for the purpose of our paper and, although the sample in this study is small, we believe that it has potential for organizational learning in a context where "history is not generous with experience" [40]. Furthermore, the study's narrative component can have a role as an example for use in classroom role-play activity.

\section{APPLICATION FOR ENGINEERING EDUCATION PEDAGOGY}

The findings would support calls for a Mode 2 approach to engineering design in syllabuses, perhaps adopting approaches similar to those described in the US [41, 42] or South Africa [43]. Initiatives like the Purdue University EPICS program [44] or Georgia Tech's Learning by Design [45] would seem appropriate approaches to develop transdisciplinary competences at undergraduate level. 


\section{A. Case-study based role-play}

To contribute to the repertoire of such approaches we would propose the use of the kind of case study and narrative approach outlined in this paper which can provide material and a framework for role-play activities suitable for inclusion in this kind of broader approach to engineering education. Our experience with the use of role-play with engineering undergraduates would reinforce Nakamura's comment that "a lack of understanding of the stakeholders' roles assigned to learners has meant that students have not really been able to fully appreciate the project management scenario that they have been roleplaying" [52]. For this reason we have found it important to build these activities around real cases which are seen to be relevant to students rather than creating hypothetical situations or using virtual simulations.

Following Felder and Brent [46], the authors consider a jigsaw activity approach to be appropriate here - one where groups of participants are supplied with different information and need to discuss or come to a consensus in a role-play. One possible application would be to use a 2stage approach. First focusing on the transition from research group to start-up in 2000, the information about research and design group Y1 (as set out in section VA of this paper) is distributed to one group of students while other receive the that of research and design group Y2 (section $\mathrm{VB}$ ). The task is for the 2 groups to share their information and to summarize the difference between the two R\&D groups. After instructor-facilitated feedback between the groups, the students learn what the real company YDreams company history was from 2000 to 2010.

The second stage would again involve 2 groups in a jigsaw activity role-playing a board meeting and in this case participants are supplied with different parts of the SWOT analysis data for the company's globalization in 2010, and similarly come to agreement on strategic options. Once again this is followed by discussion on the real company choices and their outcomes.

\section{B. Evaluation of learning outcomes}

We are still at an early stage in terms of evaluating the use of role-play and case study approach in our own institutions but as the learning outcomes to be achieved with this approach involve changes in individual students such as their perceptions of the engineer's role in the strategy management of a firm or of engineering workplace activity, phenomenography would be the method of choice. This is a qualitative methodology which focusses on the ways in which learners differ [47] with regard to specific phenomena and a useful introduction to its use in engineering education can be found in a 2007 paper by Mann and colleagues [48].

This method has been used in engineering education to evaluate size and scale in nanoscale science and technology contexts [49], and transient responses in student problem solving contexts [50]. It is also beginning to emerge in other engineering contexts as well. For example, it has been used to identify conceptions of competent work among engineers in an auto manufacturing company [51] and conceptions of the value of information-technology (IT) research among IT researchers and practitioners [52].

\section{CONCLUSIONS}

This case study of a start-up company recognized as an innovation-leader makes a contribution to two fields of study: engineering practice studies and case-study based role-play as a pedagogical tool in engineering education.

The authors applied the Gibbons Knowledge Production framework to analyse narrative accounts from two senior engineers involved in creating a start-up and identified a critical phase change which prompted the transition from a university research to an entrepreneurial context. Although, we do find confirmation for Shinn's comments regarding the limitations of this framework as guide to empirical research [30], we nevertheless were able to use the results of this qualitative narrative-based case study to design a larger scale mixed methods research project.

A further theoretical contribution of the study is that it clearly exemplifies one of the advantages proposed for small case study research [31] in that it provided serendipitous insights which led the authors to design a larger mixed methods study which in turn generated useful theory which contributed to the emergent field of engineering practice studies.

The contribution to engineering education pedagogy involves the provision of first person accounts of the transition from academia to the start-up environment which can provide appropriate examples to use in role-play activity for engineering students using a jigsaw activity approach as outlined in section VIII $A$.

Future research is expected to include a deepening the analysis of the GASA and YDreams contexts described here by enriching the interview data presented with additional data about this case such as documentary records from the contexts under study. At the same time we are looking towards acquiring similar data from other groups who have gone through a similar phase change process.

\section{ACKNOWLEDGMENT}

This work is supported by a grant from the Fundação para a Ciência e a Tecnologia (FCT) of the Portuguese Ministry for Education and Science as part of the project What Engineers Do PTDC/CPE-PEC/112042/2009

\section{REFERENCES}

[1] Anderson, K. J. B., Courter, S. S., McGlamery, T., Nathans-Kelly, T. M., \& Nicometo, C. G. (2010). Understanding engineering work and identity: a cross-case analysis of engineers within six firms. Engineering Studies, 2(3), 153-174. http://dx.doi.org/10.1080/19378629.2010.519772

[2] Domal, V. (2010). Comparing Engineering Practice in South Asia and Australia. PhD PhD, The University of Western Australia, Perth

[3] Faulkner, W. (2007). Nuts and Bolts and People. Social Studies of Science, 37(3), 331-356. http://dx.doi.org/10.1177/03063127 $\underline{06072175}$

[4] Korte, R. F., Sheppard, S. D., \& Jordan, W. (2008,). A Qualitative Study of the Early Work Experiences of Recent Graduates in Engineering. Paper presented at the Annual Confernce of the American Society for Engineering Education, Pittsburgh. June 2226

[5] Trevelyan, J. P., \& Tilli, S. (2007). Published Research on Engineering Work. Journal of Professional Issues in Engineering Education and Practice, 133(4), 300-307. http://dx.doi.org/ 10.1061/(ASCE)1052-3928(2007)133:4(300)

[6] Trevelyan, J. P. (2010). Reconstructing Engineering from Practice. Engineering Studies, 2(3), 21. http://dx.doi.org/10.1080/1937 8629.2010.520135

[7] Vinck, D. (Ed.). (2003). Everyday Engineering: An Ethnography of Design and Innovation. Boston: MIT Press

[8] Williams \& J.Figueiredo (2013), Finding workable solutions: Portuguese engineering experience in "Engineering Practice in a Global Context, Understanding the Technical and the Social" B. 
Williams, J Figueiredo and J Trevelyan, [eds.], Leiden: CRC Press, 2013

[9] Figueiredo, A. D. \& Da Cunha P. R., (2006) Action Research and Design in Information Systems, Two faces of a single coin, Chapter 5, Information Systems Action Research: Bridging the Industry-University Technology Gap, Ned Kock (Editor), Springer /Kluwer

[10] Gibbons, M., Limoges, C., Nowotny, H., Schwartzman, S., Scott, P. \& Trow, M. (1994) The new production of knowledge: The Dynamics of Science and Research in Contemporary Societies. London, Sage Publications.

[11] Jorgensen, U, (2008) Engineering Design in Theory, Teaching, and Practice - The Construction of Design Synthesis and Methods and Contemporary Challenges, submitted manuscripts, Global Perspectives on Engineering, International Network for Engineering Studies Workshop, Lisbon 2008, Accessed at http://www.inesweb.org/node/202 on 30 March 2012

[12] S.G. Baugh and R.M. Roberts, "Professional and organizational commitment among engineers: conflicting or complementing?", IEEE Trans. Eng.Manage., vol, 41, no. 2, pp 108 - 114, May 1994. http://dx.doi.org/10.1109/17.293377

[13] N. R. Kowtha, "Engineering the Engineers: Socialization Tactics and New Engineer Adjustment in Organizations", IEEE Trans. Eng. Manage., vol 55, no. 1 February 2008 http://dx.doi.org/10.1109/TEM.2007.912809

[14] Coyle, E. J., Jamieson, L. H., Oakes, W. C, Integrating Engineering Education and Community Service: Themes for the Future of Engineering Educationll, Journal of Engineering Education, Vol. 95, No. 1, January 2006, pp. 7-11. http://dx.doi.org/10.1002/j.2168-9830.2006.tb00873.x

[15] Du X., de Graaff E. and Kolmos A. (Eds), Research on PBL Practice in Engineering Education, Sense Publishers Rotterdam, Boston, Tapei 2009

[16] Abraham, N. S., Abulencia, J. P. Use of the LITEE Lorn Manufacturing Case Study in a Senior Chemical Engineering Unit Operations Laboratory, Journal of STEM Education: Innovations and Research, 2011, Vol.12(3), p.9-16

[17] Nakamura T., Taguchi E., Hirose D., Masahiro I. , Takashima A., "Role-Play Training for Project Management Education Using a Mentor Agent" vol. 3, pp.175-180, 2011 IEEE/WIC/ACM International Conferences on Web Intelligence and Intelligent Agent Technology, 2011

[18] Nakamura T., Takashima A., Mikami A., The use of agents to represent learners in role-play training, Education Engineering (EDUCON), 2010 IEEE, Madrid 17 April 2010

[19] M. A. Burton, Experiences with the Irrigation Management Game, Irrigation and Drainage Systems, 1989, Volume 3, Number 3, Pages 217-228 http://dx.doi.org/10.1007/BF01112806

[20] Sladovich, H., Ed [1991] Engineering as a social enterprise, Washington, D.C. National Academy Press, pp 2-4

[21] Bailey, D. E., \& Barley, S. [2010]. Teaching-Learning Ecologies: Mapping the Environment to Structure Through Action. Organization Science Articles in Advance, 1-25.

[22] Barley, S. R. [2005]. What we know [and mostly don't know] about technical work. In S. Ackroyd, R.Batt, P. Thompson \& P. S. Tolbert [Eds.], The Oxford Handbook of Work and Organization [pp. 376-403]. Oxford: Oxford University Press

[23] Bucciarelli, L.L. [1994], "Designing Engineers," Inside Technology, W.E. Bijker, W.B. Carlson, and T.J. Pinch [eds.], Cambridge, MA: MIT Press, 1994.

[24] Vinck, D. [2003], "Everyday Engineering: An Ethnography of Design and Innovation," Inside Technology, W.E. Bijker, W.B. Carlson, and T.J.Pinch [eds.], Boston, MA: MIT Press, 2003

[25] Faulkner, W. [2007]. Nuts and Bolts and People. Social Studies of Science, 37[3], 331-356. http://dx.doi.org/10.1177/03063127 06072175

[26] Downey, G L. 1998. The machine in me: An anthropologist sits among computer engineers. New York: Routledge

[27] Williams B. \& Figueiredo J. and Trevelyan J., [2013], Engineering Practice as an Emergent Field of Study - Implications for Engineering Educators, Proceedings of the Research in Engineering Education Symposium, REES 2013 - Kuala Lumpur
[28] L. Leydesdorff and H. Etzkowitz (eds), A Triple Helix of University-Industry-Government Relations: The Future Location of Research? (New York: Science Policy Institute, State University of New York, 1998);

[29] Gibbons, M., Limoges C., Nowotny H., Schwartzman S., Scott P., and Trow M. (ed) (1994) The new production of knowledge: The Dynamics of Science and Research in Contemporary Societies, Sage Publications, London, 1994

[30] Shinn, T. (2002). The Triple Helix and New Production of Knowledge : Prepackaged Thinking on Science and Technology. Social Studies of Science, 32(4), 599-614. http://dx.doi.org/10.1177/030631202128967271

[31] Eisenhardt, Kathleen, 1989, Building Theories From Case Study Research, Academy of Management. The Academy of Management Review, Vol 14, No 4, pp. 532-550

[32] Czarniawska, B. (2004). Narratives in social science research, Thousand Oaks: Sage.

[33] Pinnegar, S. and Daynes, J.G, (2006), Locating narrative inquiry historically: Thematics in the turn to narrative. In Clandinin D. J., (Ed), Handbook of Narrative Inquiry, Thousand Oaks, CA: Sage

[34] Denning, S., (2007) The Secret Language of Leadership: How Leaders Inspire Action Through Narrative, (pp 19-15), Wiley.

[35] Creswell and Plano Clark, Designing and Conducting Mixed Methods Research, Sage, 2011 p.71

[36] Baofu, P., (2008) The Future of Complexity: Conceiving a Better Way to Understand Order and Chaos, (pp 109 -111), World Scientific Pub Co Inc

[37] Dooley, Larry, 2002, Case Study Research and Theory Building, Advances in Developing Human Resources vol. 4 no. 3 335-354 http://dx.doi.org/10.1177/1523422302043007

[38] Flyvbjerg, Bent, 2006, Five Misunderstandings About Case-Study Research, Qualitative Inquiry, Volume 12, Number 2, pp. 219245, Sage Publications http://dx.doi.org/10.1177/1077800 405284363

[39] Eisenhardt, Kathleen and Melissa Graebner, 2007, Theory Building from Cases: Opportunities and Challenges, Academy of Management Journal, 2007, Vol. 50, No. 1, pp. 25-32 http://dx.doi.org/10.5465/AMJ.2007.24160888

[40] March, James, Lee S. Sproull and Michal Tamuz, 1991, Learning From Samples of one or Fewer, Organization Science, Vol. 2. No. 1, February 1991, pp 1-13 http://dx.doi.org/10.1287/orsc.2.1.1

[41] Dim C. et al, (2005) Engineering Design Thinking, Teaching, and Learning, Journal of Engineering Education 94 (1) 103-120. http://dx.doi.org/10.1002/j.2168-9830.2005.tb00832.x

[42] Atman C. et al, (2007) Engineering Design Processes: A Comparison of Students and Expert Practitioners, Journal of Engineering Education, 96(4), 359 -379 http://dx.doi.org/10.1002/ j.2168-9830.2007.tb00945.x

[43] Winberg, C. ( 2006) Undisciplining Knowledge Production: Development Driven Higher Education in South Africa, Higher Education: The International Journal of Higher Education and Educational Planning, v51 n2 (pp159-172).

[44] Oakes, W.C., Coyle, E.J., and Jamieson, L.H., (2000) EPICS: A Model of Service Learning in the Engineering Curriculum, Proceedings, ASEE Conference and Exhibition, Session 3630.

[45] Kolodner, J.L., Crismond, D., Fasse, B., Gray, J., Holbrook, J., and Puntembakar, S., (2003) Putting a Student-Centered Learning by DesignTM Curriculum into Practice: Lessons Learned, Journal of the Learning Sciences, Vol. 12, No. 4,. (See also http://www.cc.gatech.edu/projects/lbd/home.html)

[46] Felder, R.M., and Brent, R., "Designing and Teaching Courses to Satisfy the ABET Engineering Criteria," Journal of Engineering Education, Vol. 92, No. 1, 2003, pp. 7-25. http://dx.doi.org/10.1002/j.2168-9830.2003.tb00734.x

[47] Marton, F. (1989). Towards a pedagogy of content. Educational Psychologist, 24(1), 1-23. http://dx.doi.org/10.1207/s15326 985ep2401_1

[48] Mann, Llewellyn, Dall'Alba, Gloria and Radcliffe, David (2007). Using phenomenography to investigate different ways of experiencing sustainable design. Proceedings of the ASEE 2007 Annual Conference. ASEE 2007, Hawaii, 25-27 June 2007

[49] Carstensen, A. K., \& Bernhard, J. (2009). Student learning in an electric circuit theory course: Critical aspects and task design. 
European Journal of Engineering Education, 34(4), 393-408. http://dx.doi.org/10.1080/03043790902990315

[50] Sandberg, J. (2000). Understanding human competence at work: an interpretative approach. Academy of Management Journal, 43(1), 9-25. http://dx.doi.org/10.2307/1556383

[51] Swarat, S., Light, G., Park, E.-J., \& Drane, D. (in press). A typology of undergraduate students'conceptions of size and scale: Identifying and characterizing conceptual variation. Journal of Research in Science Teaching

[52] Bruce, C., Pham, B., \& Stoodley, I. (2004). Constituting the significance and value of research: Views from information technology academics and industry professionals. Studies in Higher Education, 29(2), 219-238 http://dx.doi.org/10.1080/030 7507042000190804

[53] COTEC 20016, António Câmara Awarded Renowned Portuguese 2006 Prémio Pessoa, COTEC Portugal online, November 2005, accessed 1/10/2013 at http://www.cotecportugal.pt/index.php? option $=$ com content\&task $=$ view $\&$ id $=140 \&$ Itemid $=319$

[54] Cresswell, John, (2007) Qualitative Inquiry and Research Design: Choosing Among Five Approaches: Sage, p. 59

\section{AUTHORS}

Bill Williams originally trained as a chemist at the National University of Ireland and went on to work in education in Ireland, UK, Eritrea, Kenya, Mozambique and Portugal. He lectures on technical communication at the Instituto Politécnico de Setúbal and at IST, Universidade de Lisboa. (bill.williams@estbarreiro.ips.pt).

José Figueiredo, Professor at the Engineering and Management Department of IST - Universidade de Lisboa, has a PhD in Industrial Engineering (Engineering and Management), an MBA in Information Management, and a degree in Electronics Engineer. While being always involved in university teaching, he also started two small companies in the information technologies sector. He currently teaches project management and communication skills. He has published several papers in international journals, international edition book chapters, and conference proceedings and edited scientific books (jdf@ist.utl.pt).

Submitted 07 October 2013. Published as re-submitted by the authors 23 January 2014. 